\title{
INCREASING AWARENESS CAPACITY OF DISASTER POTENTIAL AS A SUPPORT TO ACHIEVE SUSTAINABLE DEVELOPMENT GOAL (SDG) 13 IN LAMPUNG PROVINCE
}

\author{
Indra Jaya Wiranata ${ }^{1}$, Khairunnisa Simbolon ${ }^{2}$, Safaana Salwa Salsabila ${ }^{3}$, Hemastia Kirana ${ }^{4}$, \\ Deyna Yulian Putri ${ }^{5}$, M. Malebi Fukron ${ }^{6}$ \\ Universitas Lampung, $12,3,4,5,6$ \\ indra.jayawiranata@fisip.unila.ac.id ${ }^{1}$, khairunnisa.simbolon@ fisip.unila.ac.id $^{2}$, \\ safaana.salwa1022@students.unila.ac.id ${ }^{3}$, hemastia.kirana1002@students.unila.ac.id ${ }^{4}$, \\ deynayulianputri@gmail.com ${ }^{5}$, malebifukron60@gmail.com ${ }^{6}$.
}

\begin{abstract}
Global policies on the Sustainable Development Goals (SDGs) address several aspects of environmental life and climate change. There are still challenges that many regions do not pursue the achievement of sustainable development goals which means that SDGs cannot simply and automatically be achieved in several regions due to different contexts and different geographic backgrounds. Extreme climate change can cause natural disasters that have the potential to cause losses and even claim victims. Thus, Lampung, which is a disaster-prone area, is interesting to be studied whether the government and the community's efforts to realize potential disasters have been accomplished properly. This research explains the efforts that have been and need to be done by Lampung Province in responding to potential disasters through a policy brief in order to motivate the government to pay more attention to climate change and natural disasters. This research is a type of qualitative research with primary data that will be taken by using interview techniques and literature review. The survey was conducted by random sampling the people of Lampung regarding the level of awareness of potential disasters. The data will also be obtained by using Google Trend. The results of this research indicate that the efforts of the Lampung Provincial Government such as mitigation, emergency response, reconstruction, rehabilitation, disaster risk assessments, and support from the epistemic community.
\end{abstract}

Keywords: Awareness of Disaster Potentials, Sustainable Development Goal 13, Lampung Province

\section{INTRODUCTION}

Lampung is one of the provinces that has a long coastline and occupies the southernmost position of the island of Sumatra, and with the potential for extreme climate and great disasters. Based on data from the Indonesian Disaster Prone Index (IRBI) from the National Disaster Management Agency (BNPB), Lampung is one of the areas with high risk and also ranks 16 out of 33 provinces as a disaster-prone area in Indonesia. Disaster response efforts and awareness of the potential for disasters should be carried out by the government and related institutions, but support from the community is also an important factor in efforts to prevent losses and victims from disasters. Collaboration between parties is the key to successful response efforts and awareness of potential disasters.

The impacts of climate change can take the form of drought and pollution, but can also take the form of small or large natural disasters. The wildfires in Australia are exacerbated by the rapid spread of the fires and a wide area of 7.3 million hectares caused by the geothermal temperature in the area of $40^{\circ} \mathrm{C}$. The flash floods that occurred in Australia after forest fires and flash floods that occurred in Tanggamus, Lampung, were the impact of rainfall and extreme climate change. These disasters make awareness of climate change and disaster response actions essential to prevent casualties and losses, 
given that awareness is still low. The people of Lampung should be aware of and be able to participate in preventing the bad impacts of climate change in the future.

Sustainable Development Goals (SDGs) is a world development program issued by the United Nations (UN). The SDGs consist of global goals that call universally to take action to overcome poverty, protect the world, and ensure that all people can enjoy peace and prosperity. SDGs have 17 programs ranging from poverty and hunger eradication to the promotion of peace and justice and the principles of partnership. Apart from 17 programs, SDGs also has 169 targets that are global in nature and do not stand alone but are related to one another. In goal 13 of the SDGs, there are targets that call for strengthening resilience and adaptive capacity to the hazards of matters relating to climate and natural disasters in all countries. So that from the worsening earth conditions, increasingly extreme climate, efforts from the local level are important to do. The government and the community must understand the geographical conditions of the area, locations close to rivers, sea and hills will have greater potential than other areas. Lampung has various geographical conditions, hills, long coastlines, even valleys and swamps. Under such conditions, plans formed before a disaster occur will reduce the number of potential victims and losses, this is why disaster response and awareness efforts need to be maximized.

From these problems, research questions can be drawn, how the efforts of Lampung Province in supporting sustainable development goal number 13, urgent action to combat climate change and its impacts, through response to potential disasters?

\section{LITERATURE REVIEW}

\section{Disaster}

In general, research on disasters focuses on the natural processes by which these disasters occur and how efforts from a climate perspective to prevent them occur. Several other studies have placed the analysis on a single disaster. This research summarizes all disaster response efforts in Lampung Province, because it is related to efforts to support the achievement of SDG number 13 on climate and disaster. The definition of a disaster according to Law Number 24 of 2007, is an event or series of events that threatens and disrupts the life and livelihood of the community which is caused, either by natural factors or non-natural factors or human factors, resulting in human casualties, environmental damage, property loss. objects and psychological impact.

Types of disasters according to Law Number 24 of 2007 concerning disaster management, i.e:

A. Natural disasters are disasters caused by an event or series of events caused by nature, among others, in the form of earthquakes, tsunamis, volcanic eruptions, floods, droughts, hurricanes and landslides;

B. Non-natural disasters are disasters caused by non-natural events or series of events, among others, in the form of failed modernization technology. and disease outbreaks;

C. Social disaster is a disaster caused by an event or series of events caused by humans which includes social conflicts between groups or between communities.

D. Technology failures are all disasters caused by design errors, operation, negligence and deliberation, humans in the use of technology and / or industry that cause pollution, damage to buildings, casualties, and other damage. 


\section{Sustainable Development Goals (SDGs)}

The Sustainable Development Goals (SDGs) are a global development agenda that establishes the framework for creating a just and prosperous world. Inequality among communities in different parts of the world shows that development has not been evenly distributed, therefore, 17 SDGs were developed by the United Nations (UN) to address complex social problems. To this end, the United Nations has set an overarching goal of joint engagement in achieving these 17 goals by 2030. Educational institutions and academics have an important role to play in supporting this effort.

The SDGs program consists of 17 objectives, including:

1. End poverty

2. End hunger, achieve food security and improved nutrition and promote sustainable agriculture

3. Achieve health and a decent life

4. Realizing quality education

5. Achieve gender equality and empower all women and girls

6. Ensure availability of clean water, sustainable water management and sanitation for all

7. Ensure access to affordable, reliable, sustainable and modern energy for all

8. Promote sustainable, inclusive and economically sustainable economic growth, productive power and decent work for all

9. Building industry, innovation and infrastructure

10. Reducing inequality within and between countries

11. Make cities and communities inclusive, safe, resilient and sustainable

12. Ensure sustainable consumption and production patterns

13. Urgent action to combat climate change and its impacts In this 13 th goal, there are targets, i.e:

A. Strengthen resilience and adaptive capacity to climate-related hazards and natural disasters in all countries

B. Integrating climate change measures into national policies, strategies and plans

C. Improve education, awareness and also the capacity of both humans and institutions for climate change mitigation, adaptation, impact reduction and early warning

D. Implement the commitments made by developed country parties to the United Nations Framework Convention on Climate Change with the aim of mobilizing \$ 100 billion annually by 2020 from all sources to meet the needs of developing countries in the context of mitigation action and transparency of their implementation and fully operationalize the Green Climate Fund (GCF) through capitalization as quickly as possible

E. Support mechanisms for capacity building for effective climate change-related planning and management in least developed countries and small island developing States, with a focus on women, youth, and local and marginalized communities

14. Conserving the use of marine resources for sustainable development

15. Protect, restore and promote sustainable use of ecosystems, manage forests, combat degradation, and stop land degradation and stop the loss of biodiversity

16. Promote peace, justice, and build effective accountable and inclusive institutions

17. Partnership to achieve goals

The SDGs program operates in the spirit of partnership and pragmatism to make choices to improve lives in sustainable steps for the future of the world's next generation. So that the role of local 
government in supporting the realization of these goals is important with their respective specialties, such as Lampung with the potential for major disasters, so it is also important to pay more attention to these problems.

\section{RESEARCH METHODOLOGY}

The types of data used in this study are the types of primary and secondary data. Primary data were obtained through interviews with related parties and from surveys. Researchers used data obtained from interviews, official reports from the Lampung Province BNPB, and national data. Secondary data, namely the authors obtain the required data through various sources such as scientific journals, previous research, books, reports, and documents related to the object of research.

The research located in Lampung Province, by conducting interviews with the government and the people of Lampung Province. In this study, the authors focused on writing and analyzing the shortcomings of response and awareness of potential disasters in Lampung Province. Data will be collected using literature study and interview data collection techniques. Secondary data can be obtained from literature studies which are data collection techniques by examining the available literature such as previous research, books, journals, and newspapers. Meanwhile, primary data can be obtained from interviews with the community and related government officials as well as surveys distributed to the public. Finally, the data processing technique used is descriptive qualitative and also the presentation of data visualization with various supported graphics and images.

\section{RESULTS AND DISCUSSIONS}

\section{Climate Change And Natural Disasters And Disaster Management}

Climate change is already affecting all countries in the world. Report from UNDP, the annual economic losses caused by climate-related disasters reach hundreds of billions dollars. And even this loss does not include the impact of the disaster on humans that killed more than 1.3 million people and left 4.4 billion people injured during 1998 to 2017 (UNDP 2020). For Indonesia, our country is categorized as a country with high disaster risk as seen from the World Risk Report 2016. As many as $75 \%$ are categorized as quite vulnerable, $10 \%$ are vulnerable areas, $9 \%$ are somewhat vulnerable, $4 \%$ are vulnerable areas and 3\% are included in the category very vulnerable (IRBI BNPB, 2018).

The impact of climate change on the intensity of the recent disasters is not well understood by the public. The results of this research survey showed that out of 83 respondents, $29 \%$ of them answered that they did not really know the types of disasters caused by climate change that often occur in Lampung province. This figure was followed by $22 \%$ who answered that they knew very well, only $14 \%$ answered that they really knew, $15 \%$ answered that they did not know, and the remaining $3 \%$ answered that they really did not know. From this survey data, we can see that the community does not fully understand that the recent disasters are caused or at least exacerbated by the conditions of climate change. Even though according to BNPB, climate change is one of the factors that causes an increase in the threat of disasters (BNPB, 2019).

United Nation Offices for Disaster Risk Reduction (UNDDR) defines disaster as a serious disruption of the functioning of a community or a society involving widespread human, material, economic or environmental losses and impacts, which exceeds the ability of the affected community or society to cope using its own resources. (UNDDR, 2020). 
Sudibyakto in his book "Manajemen Bencana di Indonesia, Kemana" Defining disaster as an event that results in victims of human suffering, property loss, disaster, environmental damage, facilities and infrastructure and can cause disruption to the order of life and community livelihoods (Sudibiyakto, 2011: 1). Meanwhile, the definition of disaster in the Government Regulation of the Republic of Indonesia Number 21 of 2008 concerning the Implementation of Disaster Management is an event or series of events that threatens and disrupts the life and livelihoods of the community caused, either by natural factors and / or non-natural factors as well as human factors, resulting in human casualties, environmental damage, property loss, and psychological impact.

The factor that causes disasters is the interaction between threats and vulnerabilities (Nurjanah, 2013: 21-22). Disasters are also divided into two, i.e natural disasters and non-natural disasters. Natural disasters are disasters caused by events or a series of events caused by nature, among others, in the form of earthquakes, tsunamis, volcanic eruptions, floods, drought, typhoons and landslides. Meanwhile, non-natural disasters are disasters caused by non-natural events or series of events, which include technological failure, modernization failure, epidemics, and disease outbreaks (PP No. 21, 2007).

Natural disasters in the world are responsible for at least $0.1 \%$ of global deaths in the last 10 years. There are about 30 types of natural disasters identified worldwide where 60,000 people in more than 100 countries are regularly affected by at least one natural disaster a year. Until 2019, the relative increase in data on the occurrence of natural disasters reached $+7,120 \%$ (Ritchie \& Roser, 2019).

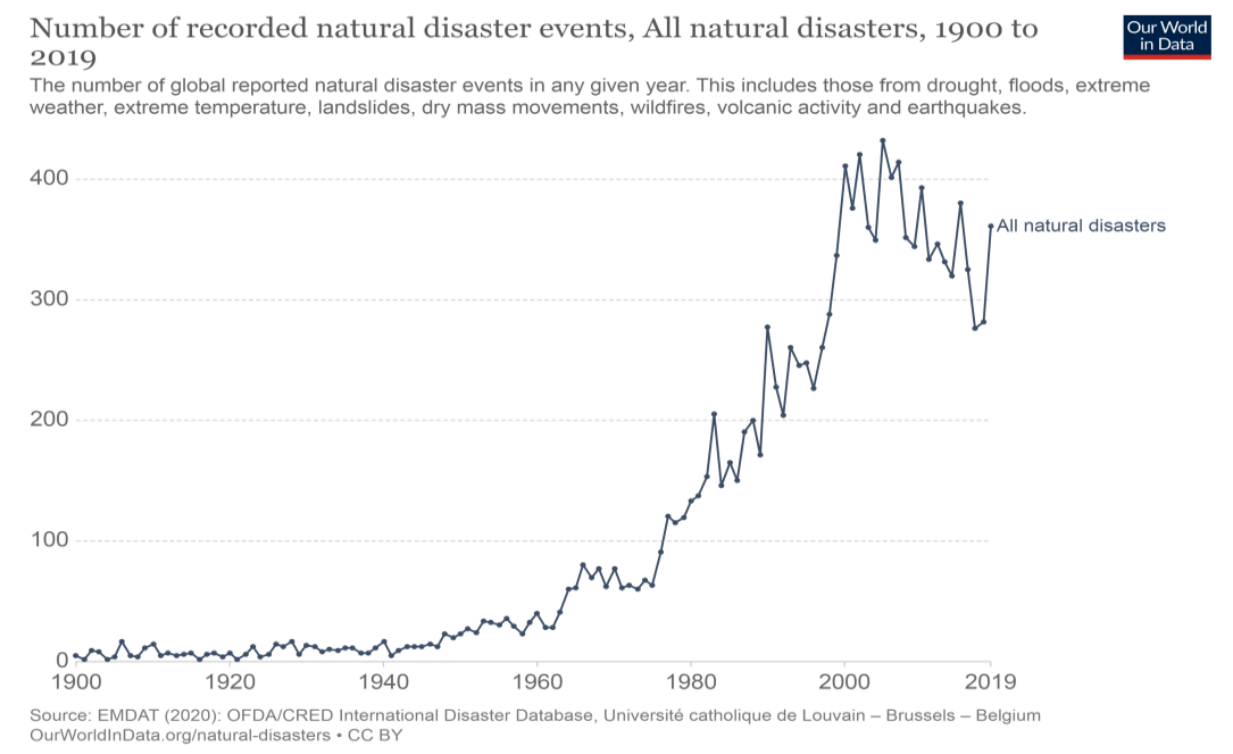

Figure 1. Number of Natural Disaster Cases from 1900-2019

Consistency in reporting of natural disasters affects the long-term trend of natural disaster events. Changes in data over time are influenced by the increasing coverage of natural disaster reporting, which means that it does not directly represent the true trend of disaster events (Ritchie \& Roser, 2019). The increasing number of cases of natural disasters is accompanied by the growth of the global population in areas that are prone to natural disasters as well as ongoing damage. The direct or indirect impact of these natural disasters makes the importance of natural disaster management in order to reduce the risk of these natural disasters. In this case, efforts for disaster management aim to reduce and / or avoid significant potential losses and ensure prompt and appropriate assistance for disaster victims so that disaster recovery for victims and affected areas can be quickly resolved effectively. (Pathirage, Seneviratne, Amaratunga, \& Haigh, 2012). 
Lampung Province has geological, topographical, climatological, hydrological, and geographic conditions that cause areas that have the potential to be affected by disasters and / or threaten and disrupt people's lives (BPBD Lampung Province, 2019). In addition, in general, Indonesia's territory is located in a series of rings of fire that stretches along the Pacific plate, which is the most active tectonic plate in the world. Due to this geographical location, almost all regions in Indonesia are at high risk of hydrometereological disasters, including Lampung Province.

In a study on disaster conditions in Indonesia conducted by the National Disaster Management Agency (BNPB) in 2013, resulted Indonesian Disaster Prone Index (IRBI). Based on the IRBI data, Lampung Province has a score of 126 with a high risk class and is in the 16th risk ranking out of 33 provinces in Indonesia (BPBD Lampung Province, 2019). The intensity of the disaster in Lampung Province can be seen in the image below. From this figure, it can be seen that the disasters that often occur in Lampung Province are varied, ranging from floods, flash floods, ROB floods, tornadoes, landslides and earthquakes, with floods and earthquakes being the most common types of disasters followed by tornadoes. In addition, other disasters that have occurred and have the potential to occur in Lampung Province were also recorded, such as extreme weather, earthquakes, trunks and forest fires.

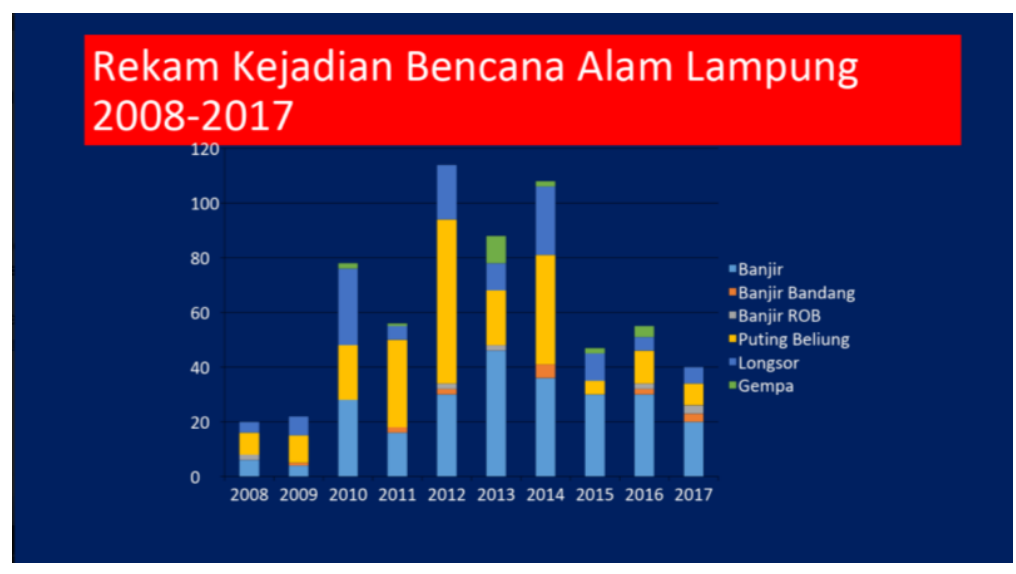

Figure 2. Records of Natural Disaster Events in Lampung Province, 2008-2017.

Natural disasters will eventually cause damage, and casualties. Based on data obtained by researchers from BPBD Lampung Province, since 2010 there have been 194 fatalities, 4,179 injured and 310,062 displaced, as a result of the disaster. In the figure below, you can also see the amount of damage to houses, educational facilities, worship and health. 


\section{Kejadian Bencana dan Dampaknya di Provinsi Lampung Tahun 2010-2019*)}

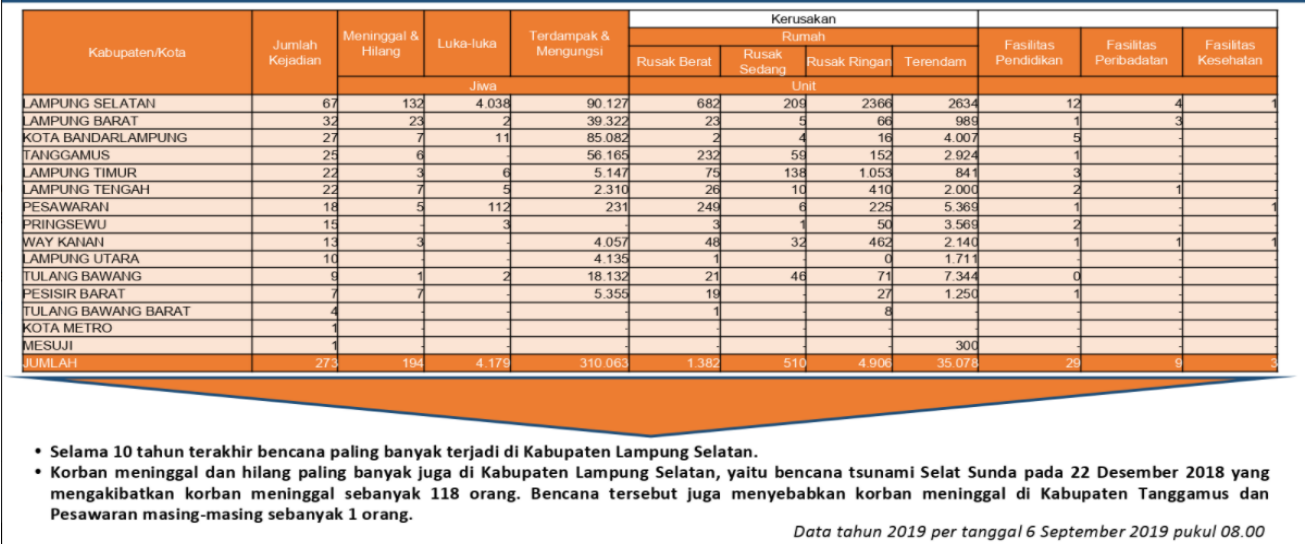

Figure 3. Disaster Incidents and Their Impact in Lampung Province in 2010-2019.

Referring to government regulations, the implementation of disaster management is a series of efforts that include the establishment of development policies at risk of disasters, disaster prevention activities, emergency response, and rehabilitation. When we refer to this definition, it can be seen that the process of implementing disaster management is very long and interrelated. Meanwhile, disaster management is a dynamic, continuous and integrated process to improve the quality of steps related to disaster observation and analysis as well as prevention, mitigation, preparedness, early warning, emergency response, rehabilitation and reconstruction of disasters (Law Number 24 of Year on Disaster Management Disaster, 2007).

The way we view disasters will result in patterns of disaster management. In the module on Improving Disaster Preparedness: Based on Science, Technology and Higher Education by Belmawa Ristekdikti, there are two perspectives in viewing disasters, namely fatalistic and risk reduction. Fatalistic means that disaster is something that is given and there is no opportunity or space for humans to prevent and try anything. The second is risk reduction, that disasters arise because of the interaction between natural phenomena and human attitudes or choices. So that in fact there is room or opportunity for us to make efforts to reduce disaster risk (Belmawa Ristekdikti, 2019).

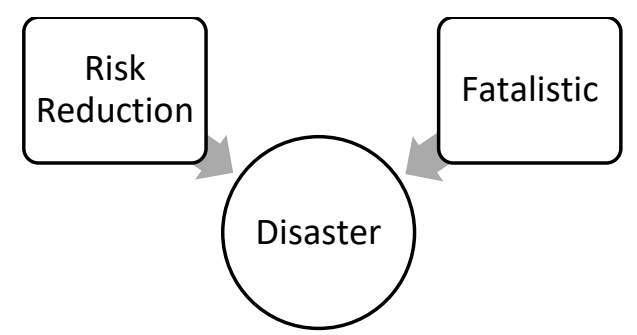

Figure 4 Disaster Perspective

Disaster management aims to minimize all types of impacts caused by natural disasters. In general, the objectives of disaster management are: (1) To prevent and limit the number of human casualties and damage to property and the environment; (2) Eliminating misery and difficulties in the lives and livelihoods of the victims: (3) Returning disaster victims from their place of refuge to their place of origin, or efforts to relocate; (4) Restoring the function of public facilities; (5) To reduce damage and further losses; (6) As well as laying the foundations necessary for the implementation of rehabilitation and reconstruction activities. 
Disaster management consists of three stages, i.e pre-disaster, emergency response and post-disaster. Its derivative activities can be seen from the scheme below which was prepared based on Law Number 24 of 2007 concerning Disaster Management. Based on this figure, it can be seen that the first stage (pre-disaster) is preventive, the second stage (during a disaster) is emergency response, and the last stage (post-disaster) is recovery. These three stages cannot stand alone and must be carried out comprehensively.

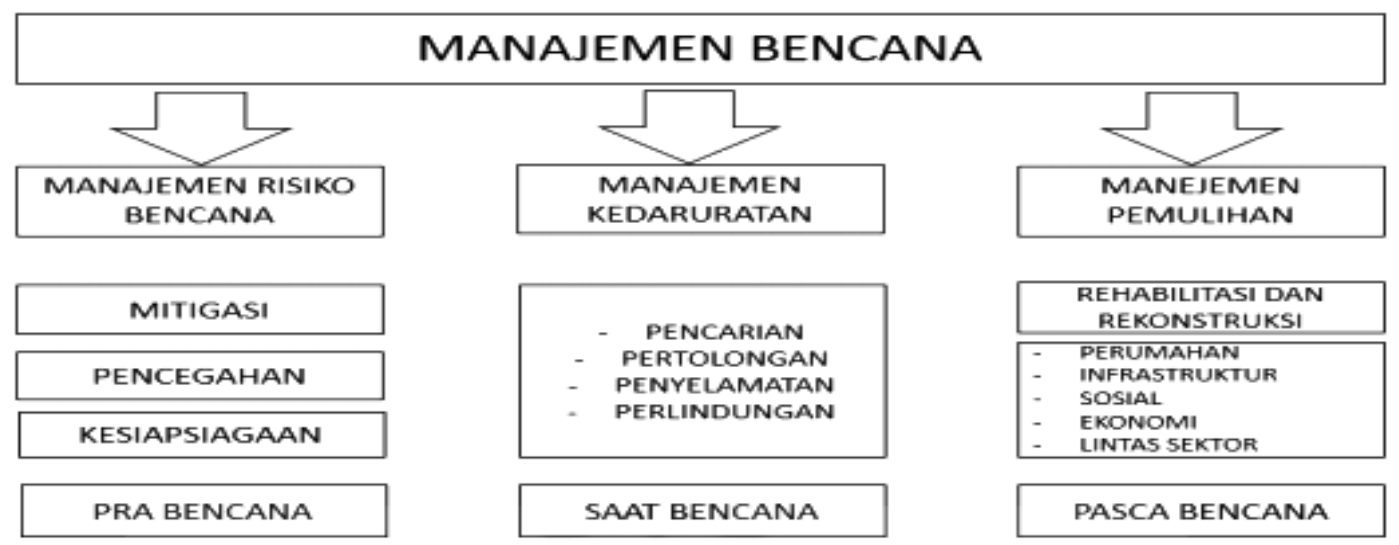

Figure 5 Disaster Management

\section{Sustainable Development Goals (Sdg): Goals 13}

Goal 13 in the Sustainable Development Goals is to take urgent action to combat climate change and its impacts. To achieve the national goal of tackling climate change by 2030 , there are several targets and indicators that must be met to achieve this goal, as can be seen in the table below:

Table 1 Targets and Indicators of the 13 Sustainable Development Goals

\begin{tabular}{|l|l|}
\hline \multicolumn{1}{|c|}{ TARGET } & \multicolumn{1}{|c|}{ INDICATOR } \\
\hline 13.1: Strengthen resilience and adaptive & $\mathbf{1 3 . 1 . 1}$ \\
capacity to climate-related hazards and & Number of deaths, missing persons and \\
natural disasters in all countries & people affected by disasters per 100,000 \\
& people \\
& $\mathbf{1 3 . 1 . 2}$ \\
& Number of countries with national and local \\
& disaster risk reduction strategies \\
& $\mathbf{1 3 . 1 . 3}$ Proportion of local governments that \\
& adopt and implement regional disaster risk \\
& reduction strategies in line with national \\
& disaster risk reduction strategies \\
\hline 13.2: Integrating climate change action & $\mathbf{1 3 . 2 . 1}$ Number of countries that have \\
into national policies, strategies and plans & communicated the establishment or \\
& operationalization of integrated policies / \\
& strategies / plans that enhance their ability to \\
& adapt the negative impacts of climate \\
change, and promote climate resilience and & development of low greenhouse gas \\
& emissions in a way that does not threaten \\
food production (including national \\
adaptation plans, nationally determined \\
contributions, national communications, \\
biennial update reports or otherwise)
\end{tabular}




\begin{tabular}{|c|c|}
\hline $\begin{array}{l}\text { 13.3: To improve education, increase } \\
\text { awareness and human and institutional } \\
\text { capacity on climate change mitigation, } \\
\text { adaptation, impact reduction and early } \\
\text { warning. }\end{array}$ & $\begin{array}{l}\text { 13.3.1 Number of countries that have } \\
\text { integrated mitigation, adaptation, impact } \\
\text { reduction, and early warning into primary, } \\
\text { secondary and tertiary curriculum } \\
\text { 13.3.2 Number of countries that have } \\
\text { communicated institutional, systemic and } \\
\text { individual capacity building to implement } \\
\text { adaptation, mitigation and technology } \\
\text { transfer, and development action }\end{array}$ \\
\hline $\begin{array}{l}\text { 13.a: Implementing the commitments } \\
\text { made by developed countries in the } \\
\text { United Nations Framework Convention } \\
\text { on Climate Change with the aim of } \\
\text { jointly mobilizing } \$ 100 \text { billion annually } \\
\text { by } 2020 \text { from all sources to meet the } \\
\text { needs of developing countries in the } \\
\text { context of meaningful mitigation action } \\
\text { and transparency of implementation and } \\
\text { fully operationalize the Green Climate } \\
\text { Fund through its capitalization as quickly } \\
\text { as possible. }\end{array}$ & $\begin{array}{l}\text { 13.a.1 The number of United States dollars } \\
\text { mobilized annually from } 2020 \text { is responsible } \\
\text { for the } \$ 100 \text { billion commitment }\end{array}$ \\
\hline $\begin{array}{l}\text { 13.b: To create mechanisms to build } \\
\text { capacities for effective climate change- } \\
\text { related planning and management in least } \\
\text { developed countries and small island } \\
\text { developing States, including a focus on } \\
\text { women, youth and local and marginalized } \\
\text { communities. Recognizing that the } \\
\text { United Nations Framework Convention } \\
\text { on Climate Change is the premier } \\
\text { international intergovernmental forum } \\
\text { for negotiating a global response to } \\
\text { climate change. }\end{array}$ & $\begin{array}{l}\text { 13.b.1 } \\
\text { The number of least developed countries and } \\
\text { small island developing States receiving specific } \\
\text { support, and the amount of support, including } \\
\text { financial, technology and capacity building, for } \\
\text { capacity building mechanisms for effective } \\
\text { climate change-related planning and } \\
\text { management, including a focus on women, youth } \\
\text { and local communities and marginalized }\end{array}$ \\
\hline
\end{tabular}

According to a report from the United Nations, 85 countries have national disaster risk reduction strategies, 55 countries report that some of their local governments have local disaster risk reduction strategies that aim to contribute to sustainable development and environmental resilience with a focus on climate change adaptation. However, not all countries in the world are able to have their own national disaster risk reduction strategies. Because there are still 33 developing countries that still do not have and formulate this strategy (United Nation 2020). Therefore, UNDP says that the main goal is to raise 100 billion dollars to meet the needs of developing countries affected by climate change to be able to adapt to climate change and be able to invest in low-carbon industries (UNDP 2020).

\section{Lampung Province's Efforts To Increase Disaster Awareness Capacity To Support The Achievement Of Sustainable Development Goals (Sdg) Number 13.}

Lampung Province is one of several local governments that have a disaster risk assessment strategy. Based on interviews conducted by the research team with the Head of the Prevention and Preparedness Division of the Lampung Province BPBD, the following table is taken from the RAD SDGs of Bappeda Lampung, Drs. Indra Utama., Dipl.Sc, in the Disaster Risk Study of Lampung Province, there were seven types of disasters that were studied. These disasters are earthquakes, 
tsunamis, tornadoes, flash floods and others. From 2017-2019, Lampung has had two disaster risk studies conducted by the Regional Disaster Management Agency whose funding sources come from the APBD and APBN.

The Lampung Province BPBD also issued a disaster study aimed at making the direction of development policies and space utilization in Lampung in accordance with the carrying capacity of the environment, especially the potential for regional disasters. It is also hoped that the Disaster Risk Assessment will have a detailed disaster map to coordinate points in the villages. Because the disaster map that is currently owned by BPBD Lampung has only reached the sub-district level marking, as can be seen in the image map below:

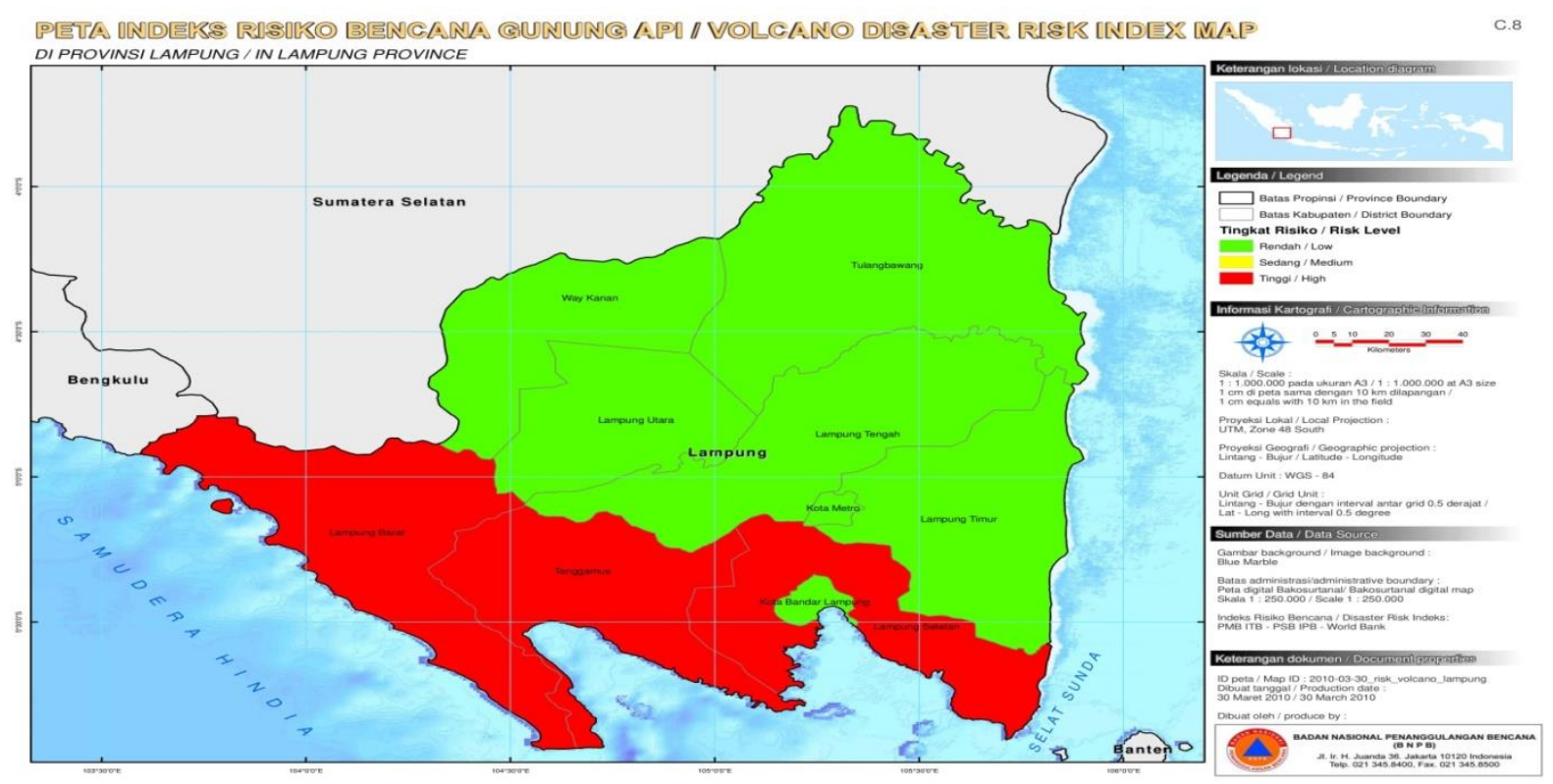

Figure 6 Map of Lampung Province Volcano Disaster Risk Index.

BPBD Lampung together with the Sumatra Institute of Technology (ITERA) is working to clarify the map to coordinate points in villages throughout Lampung Province. In addition, after the Disaster Risk Assessment has been carried out, BPBD has also planned to prepare a Lampung Disaster Management Plan (RPB), covering activities that must be carried out at the Provincial to Regency and City levels, including coordinating related institutions or agencies for handling disaster. However, these programs had to be stopped or diverted because of the Covid-19 pandemic.

Another BPBD program is the Contingency Plan, which identifies each type of natural disaster, SOP, and its category. This identification is very important to assist the government in understanding the types of disasters and their causes. By collaborating with academics (ITERA), BPBD has set targets for achieving the implementation of disaster management, for example floods. How is the condition of flood management in a district and its implementation constraints, including constraints from the bureaucracy.

For emergency response, BPBD has a team called the Quick Reaction Team (TRC). TRC is the first unit to be sent to the disaster location to check the conditions at the place of the disaster, for example, cut access roads and so on. The results of the TRC report will record the tools needed, the number of victims and access to the area. For disaster emergency response, BPBD also has an Operational Control Center (PUSDALOPS) and a Data Information Center (PUSDATIN) at the central level. After the implementation of emergency response activities, there is then a rehabilitation process that focuses on restoring the functions of community life, which is carried out in stages starting from 
restoring the function of the dwelling. After that, we will enter the reconstruction process which will rebuild the life functions of the community which were destroyed by the disaster.

Disasters cannot be stopped or predicted, but we can prepare to minimize the risk as much as possible. Based on a survey we conducted to find out the awareness of the potential disaster of the people of Lampung, from 83 correspondents, 69\% said that knowledge of being aware of potential disasters is important for the community. This means that people actually know that knowledge about potential disasters is vital for their lives, because Lampung is an area with high potential for natural disasters.

Apart from that, Lampung also carried out several other efforts to help realize the thirteenth goal of the SDGs, namely building urban resilience so that it is not directly affected by climate change in urban areas. In this case, the City Government of Bandar Lampung is collaborating with the Asian Cities Climate Change Network or ACCCN which aims to build resilience and adaptation to climate change by understanding the effects caused by developing a city resilience strategy and making it a top priority. The climate resilience strategy for the city of Bandar Lampung includes a strategy for resilience in the clean water sector, the environment sector, the infrastructure sector, the marine, coastal and fisheries sector, as well as a strategy for resilience in developing institutional capacity (Sitadevi 2016).

Apart from the government, other agencies are also trying to help achieve this common goal, namely by building a research center, namely the SDGs Center, University of Lampung. The SDGs Center continues to strive to conduct research and studies related to each goal and build a database center to facilitate monitoring and evaluation, and also build external and internal networks to collaborate in the implementation of SDGs (SDGs Center Unila 2019). According to an interview with the Head of the Prevention and Preparedness Division of the BPBD of Lampung Province, the weakness they have found so far is the lack of participation from the University as an epistemic community to assist the government in disaster studies in Lampung Province.

Mitigation or prevention efforts undertaken by the Lampung provincial government are the main focus of the Lampung Provincial BPBD. This Disaster Risk Assessment should be more disseminated to the public in order to know what programs the government has. In the end, when a disaster occurs, people are the first to feel the impact. It is only natural for the government to prepare the community as part of this mitigation effort. Based on the results of the survey conducted, of the 83 respondents, $15 \%$ already knew about the institutions that manage disasters.

Meanwhile, only $4 \%$ of the 83 respondents were aware of disaster response programs implemented by the Lampung Provincial Government. Most of the respondents, or about $31 \%$ answered that they knew well, followed by $17 \%$ who knew, $25 \%$ did not know, and as many as $6 \%$ did not know at all, as can be seen in figure 7 (7). The findings of this survey are sufficient to prove that government programs are not fully understood by the community, and not all people are aware of government programs.

Based on the survey, it can also be seen that the community does not feel that Lampung Province has implemented awareness of the potential for disasters in the community. Of the 83 respondents, only $6 \%$ thought that Lampung Province was fully aware of the potential for disasters in the community. This percentage was then followed by $6 \%$ of respondents who answered yes, $30 \%$ answered no, 33\% answered not enough, and $8 \%$ answered not at all. This indicates that the community does not feel that the Lampung provincial government is truly aware of the potential for disasters. The government needs to be more active in implementing its programs, so that people can see or feel the success and benefits of these government programs. 
In fact, when viewed from the Disaster Risk Assessment report released by BPBD Lampung Province, efforts to increase capacity are very comprehensive. The activities carried out are:

1. Strengthening policies and institutions

2. Integrated risk assessment and planning

3. Development of Information Systems, Training and Logistics

4. Thematic Management of Disaster Prone Areas

5. Increasing the Effectiveness of Disaster Prevention and Mitigation

6. Strengthening Disaster Emergency Preparedness and Management

7. Development of Disaster Recovery Systems

As a comparison, we also examined several policies of other countries related to awareness of potential natural disasters, namely Japan, New Zealand, South Korea and Switzerland. The Japanese government established the Central Disaster Management Council to focus on disaster management through making disaster management policies based on the Disaster Countermeasures Basic Act as a law regulating disaster management actions nationally. The Japanese government deals with disasters that occur quickly and responsively, providing accurate disaster development information as well as detailed government handling data from time to time. The role of the mass media as the main information provider for the development of disasters is not to dramatize the disaster but rather to build the spirit of the people for mutual cooperation and the resilience of the Japanese people. In this case, when a natural disaster occurs, the most important thing is how people can help each other and strengthen each other to be able to deal with the disaster that occurs (Barr, 2012).

The next country, New Zealand, designed a national civil defense emergency management strategy that includes a Treasury Standard of Living Framework and the types of resilience needed to protect and foster prosperity for the people of New Zealand. This strategy refers to the challenges faced by the New Zealand community including the geographic location, vulnerability and / or dangers they face. With this strategy in place, the New Zealand government hopes to become a guide for New Zealanders to look after themselves and others in times of crisis. Crisis management listed in the National Disaster Resilience Strategy (National Disaster Resilience Strategy, 2019) includes three priorities, i.e:

1. Managing Risk: risk management refers to things that can be done as preventive measures in order to minimize the risks and impacts that will be faced in the event of a disaster;

2. Effective response to and recovery from emergencies: the ability and capacity of the government to manage emergencies when they occur;

3. Enabling, empowering, and supporting community resilience (activating, empowering and supporting community resilience): building a spirit and culture of resilience in New Zealand so that its people contribute and participate in the resilience of the community and the nation.

It is known that New Zealand also has a special service unit for natural disasters, namely the National Crisis Management Center from the New Zealand government. They work at Beehive Bunker, an integrated service center in natural disaster management that is used as a refugee for residents to a center for distributing information for the media. As long as there is no disaster, this place is used as a 'laboratory' for disaster simulation and socialization of the Wellington community (Stewart, 2016).

Meanwhile South Korea is very vulnerable to various natural disasters including: typhoons, floods, drought, landslides, snowstorms, tsunamis, to earthquakes, disaster risk management in South Korea depends on the full involvement of local governments and the central government assisted by national hydrometeorological services. and universities to the private sector. Increased urbanization has prompted South Korea to take preventive measures with reference to the welfare of its people and 
their economy. South Korea considers that consistent and accurate information related to climate change is important because it can endanger the population and the economy.

The commitment of the Republic of Korea (Dolcemascolo, Kim, \& Mu, 2011) in reducing the impact of natural disasters has carried out various ways including

1. Improving land use planning especially on floodplains and on steep slopes;

2. Raising building standards for schools, hospitals and other essential infrastructure;

3. Improving forest and wetland protection;

4. Strengthening early warning systems and preparedness capacities;

5. Delivering of information about the climate in the Republic of Korea with good and accurate.

Switzerland, not only prepares its people in mitigating natural disasters. But also disasters that can arise due to man-made technology, as well as social disasters that can happen at any time. According to research conducted in Switzerland, people mostly prepare themselves with a food supply that can last for 7 days, and water that can last for 3 days. But for the supply of basic medical protection tools such as mouth and nose masks, gloves, and others, very few are prepared. (Maduz, Prior, Roth, Kaser. 2019). But not only that, Switzerland has several tools in climate mitigation in the energy sector, i.e:

1. Cross-sectoral policies, which means that Switzerland issues policies to reduce greenhouse gases. There are four policies issued, namely the Law regarding $\mathrm{CO} 2$ emission reduction, which provides a tax on the use of fuel that produces $\mathrm{CO} 2$ even though motorized transportation is not included in this policy because the target of this policy is the industrial sector. In addition, there is also a Swiss emission trading scheme, as well as negotiations for a commitment to reduce $\mathrm{CO} 2$ emissions.

2. Energy sector specific tools, in this case the most important thing is the 2050 energy strategy which has four points, namely:

a. A new law which can contain more details regarding energy reduction.

b. The electricity supply from renewable energies such as water and wind is maximized.

c. Re-structuring energy storage systems as well as electricity transmission lines properly across the region.

d. Research in the energy sector is further strengthened.

3. Building sector-specific tools, there are two ways, namely through the improvement program in the national development sector, and building cantonal codes.

4. A special tool for the transportation sector, the first of which compensates a portion of the $\mathrm{CO} 2$ emissions generated from motorized engines. Second, by renovating energy-efficient buildings. Meanwhile, technology mitigation in the transportation sector is by replacing motorized vehicle engines with machines that are more energy efficient, as well as biofuels. From several examples of the countries above, there are forms of disaster risk management which are an important basis for minimizing risk and / or being steps in handling when a disaster occurs (Strong, Carpenter, \& Ralph, 2020):

1. Response

The speed and accuracy of the response from the government to relevant stakeholders when a disaster occurs is very important to minimize casualties and prevent ongoing damage. Good preparation through disaster management planning or scenarios is needed to facilitate evacuation, search and rescue, and provision of assistance to meet the needs of victims.

2. Recovery

The recovery process is to restore the physical, social, economic, cultural and environmental systems to their original state or to become more stable quickly and successfully based on every community, nation and other group. Recovery includes returning the refugee population to their homes, restoring critical and unnecessary public services, and enabling economic functionality. 3. Mitigation 
Mitigation refers to the elimination or reduction of the harmful effects of a disaster that occurs. It focuses on reducing mortality, economic loss, and environmental degradation. Mitigation must consider the culture, weaknesses and capacities of stakeholders.

4. Preparedness

Alertness and preparation for dealing with disasters includes knowledge and ability to anticipate and reduce the impact of disasters. Resource planning and logistics are key mechanisms for increasing the capacity of respondents and can range from ensuring basic infrastructure and services, to developing early warning systems and evacuation plans, and training response personnel to act effectively and according to their roles.

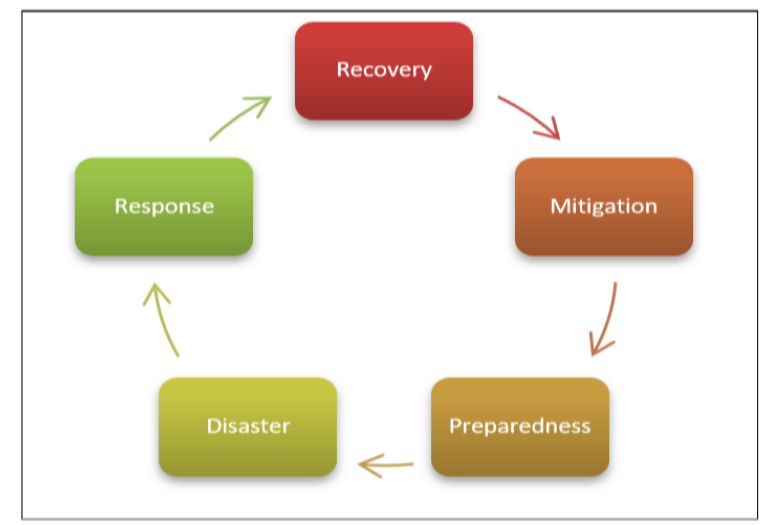

Figure 7 The Disaster Risk Management Cycle

Education on awareness of natural disasters aims to increase understanding of the man-made elements of disasters, threats and vulnerabilities and to provide an understanding of how to attack the causes and prevent them (Gustafsson \& Khorram-Manesh, 2017). Community participation is very important to reduce the risk of this natural disaster. For example, in Japan, to be precise in Kobe, not only through adequate government programs, the character of Japanese society is instilled from an early age to be tough and have a hard work spirit, to become independent. When a disaster occurs, Japanese people prioritize accurate information on the progress of the disaster evacuation process rather than sad stories that discourage its citizens. The Japanese government also implements three different levels of community security (Saputra, 2014).

1. Household level, this refers to the formal education children get from school. Three things must be considered at this level, namely community activities, raising awareness of locally based disasters, and establishing a safe and comfortable environment.

2. Sub-district level, this refers to daily activities carried out at the household level but there is coordination between residents and local government in disaster management.

3. District level, this refers to rescue activities through the sub-district head office for the community through emergency services in the form of coordination of assistance for disaster victims, volunteer activities, and dissemination of accurate information about disasters.

The success of disaster management practices in every country in the world cannot be separated from the role of the community or citizens. Awareness and compliance with policies made by the government is a big support for the government in reducing the risk or impact of disasters. Comprehensive socialization from the government to proper handling according to a good scenario can reduce the risk of a disaster that occurs. The Lampung government can make these countries a comparison and learn from their experiences in handling disasters to help increase awareness of potential disasters. With the increase in government capacity, it is hoped that a top-down effect will occur and the capacity of the community will also increase. The end result will culminate in meeting the 13 SDGs on climate change goals. 
Climate change and its impacts are in front of our eyes and its impacts are real. The community as the party most affected is the main target of the goals of the 13th SDGs. Strengthen resilience and adaptive capacity to climate-related hazards and natural disasters in all countries; Integrate climate change action into national policies, strategies and plans; Implement the commitments made by developed countries in the United Nations Framework Convention on Climate Change with the aim of jointly mobilizing $\$ 100$ billion annually by 2020 from all sources to meet the needs of developing countries in the context of meaningful mitigation action and transparency of implementation and fully operating the Green Climate Fund through its capital as quickly as possible; creating mechanisms to build capacities for effective climate change-related planning and management in least developed countries and small island developing States, including focusing on women, youth and local and marginalized communities; Recognizing that the United Nations Framework Convention on Climate Change is the premier international intergovernmental forum for negotiating a global response to climate change. Almost all of these targets are aimed at the community, but the main point lies in the policies originating from the government.

The Lampung government as a policy maker at the provincial level is an important key in the successful implementation of SDGs in Lampung. For this reason, the efforts made by all levels of local government are an important factor in increasing the capacity to realize the potential disasters of the Lampung people themselves. In this case, according to the research team, based on the results of tracing and analysis of secondary data, interviews and surveys, all forms of efforts, including activities, programs and coordination between related agencies and institutions, still need to be improved.

\section{CONCLUSION}

The initial purpose of this research is expected to increase knowledge, attitudes, and understanding by the community about the potential disaster in Lampung Province. This research is also expected to explain the efforts that have been and need to be made by the Lampung Provincial Government in responding to potential disasters as the achievement of goal number 13 SDGs.

Lampung Province has geological, topographical, climatological, hydrological, and geographic conditions that cause areas that have the potential to be affected by disasters and / or threaten and disrupt people's lives (BPBD Lampung Province, 2019). In addition, in general, Indonesia's territory is located in a series of rings of fire that stretches along the Pacific plate, which is the most active tectonic plate in the world. So that the Lampung provincial government needs to increase its capacity in the field of awareness of potential disasters.

The efforts made by the Lampung government all refer to the regulations issued by the central government through various laws and regulations governing disasters in Indonesia. As for some of the efforts of the Lampung Provincial government such as Lampung Province, which is one of several local governments that have a disaster risk assessment strategy, they are:

1. Lampung has two disaster risk studies carried out by the Regional Disaster Management Agency whose funding sources come from the APBD and APBN;

2. The Government of Lampung through the Lampung Provincial BPBD has also planned to prepare a Lampung Disaster Management Plan (RPB), covering activities that must be carried out at the provincial to district and city levels, including coordinating disaster management related institutions or agencies;

3. Another BPBD program is a Contingency Plan, which identifies each type of natural disaster, SOP, and its categories; 
4. For emergency response, BPBD has a team called the Quick Reaction Team (TRC);

5. Lampung Province, through the City Government of Bandar Lampung, collaborates with the Asian Cities Climate Change Network or ACCCN which aims to build resilience and adaptation to climate change by understanding the effects of developing a city resilience strategy and making it a top priority;

6. And the last one from the epistemic community, namely SDGs Center UNILA. The SDGs Center continues to strive to conduct research and studies related to each objective and build a database center to facilitate monitoring and evaluation, and also build external and internal networks to collaborate in the implementation of SDGs.

Based on the explanation from the previous chapters, the Lampung government as a policy maker at the provincial level is an important key in the successful implementation of SDGs in Lampung. For this reason, the efforts made by all levels of local government are an important factor in increasing the capacity to realize the potential disasters of the Lampung people themselves.

\section{LIMITATION AND STUDY FORWARD}

Based on the results of tracing and analysis of secondary data, interviews and surveys, all forms of efforts still need to be improved, including activities, programs and coordination between related agencies and institutions. Due to Covid-19 some research plans could not be done. This is resulted in unsuccessful research outcomes. We originally planned to produce a policy brief. For further research the suggestion that can be given from a scientific perspective on International Relations is to apply the concept of para-diplomacy through a sister city. We can see the success of D.I Yogyakarta and its Sister City in transferring knowledge about disaster management. We hope that the next research can discuss this matter.

\section{ACKNOWLEDGEMENT}

This research was funded by the Institute for Research and Community Service (LPPM), University of Lampung. The research team would like to thank LPPM for the financial and other support to our research team. With the assistance of LPPM, this research can be completed properly and on time.

\section{REFERENCES}

Barr, H. (2012). Lessons from the disaster: Risk management and the compound crisis presented by the Great East Japan Earthquake. Journal of Interprofessional Care, 26(4), 343.

Brandenberger, F. (2018). Climate Changes Mitigation in Switzerland. Thailand.

Civil Defence - Emergency Management. (2019, February 26). Dipetik September 8, 2020, dari Greater Wellington Regional Council: https://www.gw.govt.nz/civil-defence-emergencymanagement/

Disaster Prevention Information. (2020, Agustus 4). Retrieved September 7, 2020, from Tokyo Metropolitan Government: https://www.metro.tokyo.lg.jp/english/guide/bosai/index.html

Dolcemascolo, G., Kim, Y., \& Mu, T.-L. L. (2011). Reducing Disaster Risk in Cities - the Republic of Korea's Experience. Retrieved September 5, 2020, from World Meteorogical 
Organization: $\quad$ https://public.wmo.int/en/bulletin/reducing-disaster-risk-cities$\% \mathrm{E} 2 \% 80 \% 94$-republic-korea\%E2\%80\%99s-experience

FAO. (2020). Sustainable Development Goals. Dipetik September 4, 2020, dari http://www.fao.org/sustainable-development-goals/goals/goal-13/en/

Gustafsson, K., \& Khorram-Manesh, A. (2017). Public Education. In A. Khorram-Manesh, Handbook of Disaster and Emergency Management (pp. 114-116). Gothenburg: Institute of Clinical Sciences Sahlgrenska Academy Gothenburg University.

Kienholz, H., Krummenacher, B., Kipfer, A., \& Perret, S. (2004, April). Aspects of Integral Risk Management in Practice - Consideration with Respect to Mountain Hazards in Switzerland. Swiss.

Maduz, L., Prior, T., Roth, F., \& Kaser, M. (2019). Individual Disaster Preparedness: Explaining Disaster-related Information Seeking and Preparedness Behavior in Switzerland. Zurich.

(2019). National Disaster Resilience Strategy. Ministry of Civil Defence \& Emergency Management, New Zealand Government.

Pathirage, C., Seneviratne, K., Amaratunga, D., \& Haigh, R. (2012). Managing disaster knowledge: Identification of knowledge factors and challenges. International Journal of Disaster Resilience in the Built Environment, 3(3), 237-252.

Ritchie, H., \& Roser, M. (2019). Natural Disasters. Retrieved from Our World in Data: https://ourworldindata.org/natural-disasters\#link-between-poverty-and-deaths-fromnatural-disasters

Saputra, R. S. (2014). Pencegahan Bencana Kota Kobe Pasca Gempabumi Kobe 1995.

SDGs Center Unila. (2019). Our Projects. Dipetik September 8, 2020, dari https://sdgcenter.unila.ac.id/our-project/

Sitadevi, L. (2016). Membangan Ketahanan Kota terhadap Dampak Perubahan Iklim: Studi Kasus Kota Bandar Lampung. Jurnal Perencanaan Wilayah dan Kota Vol. 27, No. 3., 190-207.

ssunha. (2017, Desember 28). Disaster Response System of Seoul Metropolitan Government. Retrieved September 8, 2020, from Seoul Solution: https://www.seoulsolution.kr/en/content/7605

Stewart, M. (2016). Concerns raised after Beehive's disaster response bunker takes in floodwater. Dipetik September 4, 2020, dari stuff: https://www.stuff.co.nz/national/nzearthquake/86563025/concerns-raised-after-beehives-underground-disaster-responsebunker-takes-in-floodwater

Strong, K., Carpenter, O., \& Ralph, D. (2020). Scenario Best Practices: Developing Scenarios for Disaster Risk Reduction. Cambridge Centre for Risk Studies at the University of Cambridge Judge Business School and Lighthill Risk Network. , 12-15.

Tokyo Metropolitan Government spearheading disaster preparedness efforts. (2019, Agustus 7). Retrieved September 7, 2020, from The Japan Times: https://www.japantimes.co.jp/2019/08/07/special-supplements/tokyo-metropolitangovernment-spearheading-disaster-preparedness-efforts/

UNDP. (2020). Goal 13: Climate Action. Dipetik September 4, 2020, dari https://www.undp.org/content/undp/en/home/sustainable-development-goals/goal-13climate-action.html 
United Nation. (2017, July). Japan's Voluntary National Review: Report on the Implementation of the Sustainable Deevelopment Goals. Dipetik September 8, 2020, dari Sustainable Development Goals United Nation: https://sustainabledevelopment.un.org/content/documents/16445Japan.pdf

United Nation. (2020). Progress towards the Sustainable Development Goals. United Nations. 